Biannual Research Journal Grassroots

Vol.55, No.II, 2021: 164-176

Grassroots

\title{
AN ANALYSIS OF CODE-MIXING AND LOAN WORDS OF ENGLISH IN SINDHI PRINT MEDIA
}

\author{
Nadir Ali Mugheri \\ PhD Scholar Institute of English Language \& Literature (IELL), University of Sindh \\ Email:nadirmugheri@yahoo.com \\ Jehanzeb Khan \\ PhD scholar at Institute of English Language \& Literature, University of Sindh \\ Email: jehanzeb1978@gmail.com \\ Ali Siddiqui \\ PhD scholar at Institute of English Language \& Literature, University of Sindh \\ Email:scorpionking2893@outlook.com
}

\begin{abstract}
English is amongst the most commonly articulated languages on the Earth. It led to a significant effect on its growth. In Pakistan, English is utilized at all educational levels. Therefore, its development is unaffected rather natural. The phrases and words of other languages can be easily combined with English language, hence it is spread widely. In Sindh province of Pakistan, the English words and phrases are recurrently mixed and borrowed with the Sindhi language. They are used in the news items of Sindhi print media frequently. The technique of code-mixing and loan words is noticed in both, written (in newspapers) and spoken (on news channels) form of the language. The research works on the degree of occurrence of code-mixing and loanwords in Sindhi print media in Pakistan. The fundamental parts of multilingualism and bilingualism changes and mixes both languages that have been shown in this article. This propensity to exchange and mix codes caused a notable change in the minds of Sindhi newspaper readers of the Sindh province and Sindhi culture is passed through many parts of Sindh. The impact to mix Sindhi and English words in the culture of Pakistan has also been shown in this research. Investigations have been conducted by the utilization of subjective strategies. Patterns of code blending in Pakistan have been partitioned into three main categories: They are level of sentence, grammatical form and level of word's classification. In Sindh, the highest number of code-mixing is shown at the word level. The readers of the Sindhi tabloids are progressively keen on English learning. The level of English code-mixing has been shown by the results of this research.
\end{abstract}

Keywords: Loanwords, Mixed Codes, English language, Sindhi print media 


\section{INTRODUCTION}

The study of Weirich and Haugen began in the mid-1950s comprised of the study of development in communication in different languages. A broader phenomenon of communication is the mixing of words of multiple languages for effective communication that is manifested as mixing of codes. Similar to the scrambling and transcoding, mixing and exchanging of codes has been reflected as a highly significant and common methods in communication amongst the bilingual or multilingual people, as both of these phenomena are substantial techniques of effective communication. English language was brought in the Sub-continent in British rule that laid the foundation of bilingualism in Pakistan and introduced this language phenomenon in the Pakistani culture. English is considered a prestigious language in Pakistan, and with every passing day its importance is being increased. In their daily lives, multiple languages or different dialects are sub-consciously or consciously been mixed during the communication of Pakistani people. Occasionally, during conversations, in order to accomplish the purpose of communication words and the phrases of different languages, they tried to mix code from time to time or in one language to another. This trend in sociolinguistics shall mix and change coding behaviour and transform into a significant aspect of language. Considerable attention has been given in the modern era. The combination of different languages is being utilized in regular discussions along with advertisements, newspapers, and digital media even in the magazines. In Pakistan, the issue regarding language has always been very profound, as "language variants have a social and political background" (Heller, 2007). It leads to impulsive responses from different sectors of the population. In inclusion of Sindhi as the official language of the Sindh province, English along with over 70 provincial languages are regularly spoken all over Sindh and Pakistan. The clash among English and Sindhi has brought forward calamitous concerns. With that perspective, globalization has caused a substantial influence on the multilingual environment of Sindh, Pakistan. For that reason, English language is now a crucial part of the Sindhi society. An important method to spread English in Sindh rather than in the entire country is the lending of mixed codes from English language and their incorporation into Sindhi language on multiple Sindhi media platforms. Sindh, being a multilingual society is exposed to the practice of borrowing phrases 
from English language to be mixed with regional dialects. Sindhi has been an old language of Subcontinent but being one of the renowned languages, Persian, English, Hindi, Arabic, and various different languages have put its influence in its development. Subsequent to British settlement in the Subcontinent, English was turned into the official language in the socio-political context and it employed an eternal impact on dialects of Hindi, Urdu and Sindhi. In the previous decades, the growth of English as an international language caused it to be utilized frequently in many different regions of the world along with their native languages with Sindhi in Pakistan. In modern society, Sindhi print media has developed into an essential means of communication, specifically through number of newspapers and news agencies. Currently, the attention is being paid to the political and economic situation of the country by the common people. Almost every Sindhi newspaper man oeuvres to acquire "rating scales" to shape the news of various arenas. The tabloids always keep their language updated in order to keep the readers attracted, engrossed and fascinated. Media, language and society are associated in respect to the culture of the country in a contented link (Rasul, 2006). Sindhi print media is portraying a multifaceted character: first, it represents the common population, and it tends to shape the intellect of the people of the province. English is considered as the language of elite people in Sindh. The Sindhi print media now and then utilizes words of English language in its news, advertisements and headings with occasionally it switches to English from Sindhi especially in articles and opinions that are published in the editorial page. This Phenomenon of socio-cultural nature, which is a crucial part of sociolinguistics, is being reflected in different platforms of Sindhi digital, social and print media.The society in general is accepting it wholeheartedly as the code-mixing and loanwords enrich, deepen and develop the Sindhi language.

\section{LITERATURE REVIEW}

In bilingual societies, the conversion of codes, code mixing and borrowing of loan words is a common practice that is observed in dayto-day talks, on radio, television, magazines, newspapers, and the internet. Mugheri and Lohar (2018) established that the exploration additionally uncovered the blending of English code and turned into a fundamental piece of information. It is used to record, report composing and article that letters in the English phrases. It readily 
yield enormous number of nearly forty million Sindhi talking individuals in whole Sindh, a few areas of Balochistan, Punjab and power passageways to Islamabad. They further disclosed that blending of English code is routinely and normally acknowledged in the report that composes and documents news that later becomes the part of tabloids. "The code-blending is every now and again just as unexpectedly embraced and concurred in the news items and articles of the Sindhi tabloids (Mugheri and Lohar, 2018). The other researchers have tried to elaborate the behaviour of code-mixing in languages. The studies of Amuda (1989), Martin (1998) and Anzaro (2018) are worthy to mention. They defined the switching of codes as the best point to selectively use at least two vernacular languages, the language assemblies, and even language styles. Bokamba (1989) likewise have articulated his estimations on the idea to mix the code. According to Spolsky (1998), "It is very important for people to develop some data and constraints in a tiny language so that they may clearly become bilinguals". The task with minimum difficulty in bilingualism is the working on an insignificant language. Few beneficial limits are present in it can range from restricted presence in one place to a great claim in other areas. As stated by Wardhaugh (1992) "conversational coding involves the ability to mix two languages without changing the subject matter". Coding has been described by Hudson (1996) as "in this case, having a pleasant bilingual conversation with another comfortable bilingual will change the mother tongue without changing the situation". It was further stated that "In order to achieve the correct effect, the speaker will switch between the two languages in an unusual way, like a voice mixture".

Sindhi has the prestige of the official language since the creation of Pakistan, nevertheless, "Certain elements are generally accepted, suspicious problems with technical language and unexpected factors other than English" (Rasul, 2009). With the emergence of the first rays of light, industrialization and globalization have enriched the atmosphere of English. English has now gained its position in Pakistan's semantic hierarchy that has created a frustrating circumstance for the officials.

Loan words and Mixing of Codes: According to Crystal (1987) when a bilingual individual switches from one language to another 
during conversation with another bilingual individual, there will be confusion in the codes of the language. Conversion of codes is a technique cause people to switch from one language to a different one during dialogue delivery. When two languages are being utilized at the same time, the confusion will occur especially when speakers switch from one language to another during the process of pronunciation. In the linguistic field, the morphological borrowing of codes is the practice to modify a word of one language for its utilization in a different language. The words acquired by this phenomenon are known as loan words. Some of the words are used to denote society, objects, social and political organizations, thoughts or theoretical proceedings that are not the part of culture of another language. These words in a specific language do not possess a common implication in another language. The terms change through switching of code and borrowing. As part of a language, codes may be as minor as morphemes or as extensive and multifarious as the complete arrangement of a sentence (Ayeomoni, 2006).

Coding comprises of "combination of the components of a language for at least two or more languages into the same expression in different ways" (Ho, J. W. Y., 2008). Mixing of codes is an approach to transfer units of a language such as phrases, morphemes, sentences or even words from one language to another (Kachru, 1983). Mixing of codes emphasizes on the blending of two different languages at the level of sentences, whereas trans-coding contains the mixing of codes for no less than two different languages at the grammatical level of the sentence (Poplack, (2001).

\section{SIGNIFICANCE OF STUDY}

In Pakistan society, there are is use of different languages. The study focuses on utilization of mixed codes and borrowing of words in local languages. It is a significant study because it tends to observe a phenomenon that is commonly being observed in print media. In order to understand the socio-linguistic culture of Pakistan, this study holds a great importance. One more implication of this research is the revelation of the focus of language that is utilized in Sindhi print media which is not stable in Pakistan. 


\section{RESEARCH OBJECTIVES}

Following research objectives are being focused in the current study:

1. To comprehend the Pakistan's socio-linguistic culture.

2. To determine the patterns and reasons behind code-mixing in Sindhi print media.

\section{RESEARCH METHODOLOGY}

Data for the research was collected from the Sindhi print media. Five leading newspapers that included Daily Awami Awaz, Daily Ibrat, Daily Koshish, Daily Sobh and Daily Pahenji Akhbar were selected to gather the data of an entire month. A total of 150 publications of all five leading newspapers were downloaded to acquire the data. Besides this, the interviews of 15 editors and reporters of newspapers were recorded in order to observe their viewpoint about code-mixing and its impact on Sindhi language. Empirical qualitative method has been utilized for this study. The range of coding in Sindhi print media has been categorized into two main groups: phrase type and parts of speech. The extent of occurrence of this pattern in the everyday editions of newspapers has been brought from all the stations and analyzed in this research.

\section{DATA ANALYSIS}

When there is no fluent communication amongst the bilinguals in the same language, the conversion of codes, confusion in codes and borrowings do occur. Modern literary practices and rituals are imitated by the print media that is similar to other societal brands. Daily news items have been combed to extract data for the study.

The language of newspapers has transformed in the previous decades. Many phrases and words like "headline, headings, breaking news, update, pause, sports, games and etc." that were being utilized in Sindhi previously are not presented nowadays. Careful review of the documented communications has revealed that the mixing of code in Sindhi print media is a common practice in Sindhi print media. Even though the equivalent words of English language are available in Sindhi, however, these are not utilized in everyday practice. For instance, terminologies like, suitcase, e-mail, curfew, record, chief justice, glass, table, match, etc. are always written in English language and are well understood by the general population. 
Furthermore, interpretation of the data has revealed that the words of English have very common equivalents in Sindhi such as international, national, functional etc. are also communicated in English.

\section{RESULTS}

Words of English language utilized in Sindhi print media have been given in comparison to their equivalent Sindhi words and been listed below:

\begin{tabular}{|c|c|c|}
\hline Email & Barki maraaslo & برقي مراسلو \\
\hline Party & Jamaat & 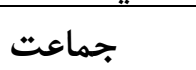 \\
\hline Break & Waqfo & وقفو \\
\hline Record & Mehfooz Karan & محفوظ كرط \\
\hline Chief justice & Musnafan-jo-sarbraah & جوسربراهـ \\
\hline
\end{tabular}

WORDS OF ENGLISH WITH THEIR EQUIVALENTS IN SINDHI PRINT MEDIA DURING SEPTEMBER 1-30, 2021

Two major categories of switched codes have been given:

- Code-switching between words

- Code-switching between sentences

Fundamentally, utilization of switched codes takes place among whole sentences. This illustration demonstrates the type of code changing in English that is used at the sentence level in Pakistan.

- Sheenh jo putt (courageous) (بهادري) شينهن جويت)

- Maanhu jo putt (idealistic or noble) مثالي. عظيم) ماطهوجويت

In the above given example, the equivalent Sindhi phrases demonstrate the Pakistani social and cultural traditions, along with the behaviours and psychological status that is a part of the structure of sentences in English language.

"Aslam has well said that the contemporary technology and the city life have made our lives be-rung" (Colourless).

In above given illustration, a sentence in English language comprises of a word related to Sindhi language. Such kind of codemixing is very uncommon in Sindhi print media. 
هin police wat bayaan record karaayo هن يوليس وت بيان ركارب كرايو "He recorded his statement with the police"

سرفراز حسين اث رنس ناهي ورتيون Sarfraz Hussain atth "Sarfraz Hussain made eight runs"

Interesting interpretations have been displayed by utilization of mixed codes phenomena in the above stated examples.

As stated previously, mixed codes are those words in a language that have equivalent words but still they are blended with another language as a common practice.

Some common words that have Sindhi equivalents but are still used with English counterparts are listed below:

\begin{tabular}{|c|c|c|c|c|c|}
\hline Fashion & Rivaaj & رواج & Cup & Piyali & ييالي \\
\hline Bag & Thelho & تيلهو & Date & Tareekh & تاريخ \\
\hline Student & Shagird & شاگرد & Result & Nateejo & نتيجو \\
\hline $\begin{array}{l}\text { Chief } \\
\text { Minister }\end{array}$ & $\begin{array}{l}\text { Wazir- } \\
\text { e-Aala }\end{array}$ & وزليرِ & Report & Tahqiqi Dastaveez & تحقيقي دستاويز \\
\hline Alliance & It'haad & اتحاد & FIR & $\begin{array}{l}\text { Ibtdaai jaach waro } \\
\text { dastaaviz }\end{array}$ & ابتدائي جاج وارو \\
\hline
\end{tabular}
media.

Words of English language utilized frequently by Sindhi print

\begin{tabular}{|c|c|c|c|c|c|}
\hline $\begin{array}{l}\text { Compartment } \\
\text { كميارتمينت }\end{array}$ & $\begin{array}{l}\text { Fashion } \\
\text { فيشن }\end{array}$ & $\begin{array}{l}\text { Advance } \\
\text { ايبو انس }\end{array}$ & $\begin{array}{l}\text { Mood } \\
\text { موبج }\end{array}$ & $\begin{array}{l}\text { Law } \\
y\end{array}$ & $\begin{array}{l}\text { University } \\
\text { يونيورسنتي }\end{array}$ \\
\hline $\begin{array}{l}\text { Lunch } \\
\text { لنج }\end{array}$ & $\begin{array}{l}\text { Accident } \\
\text { ايكسيدنت }\end{array}$ & $\begin{array}{l}\text { Airport } \\
\text { ايئريوروت }\end{array}$ & $\begin{array}{l}\text { Transfer } \\
\text { تر انسففر }\end{array}$ & $\begin{array}{l}\text { Corruption } \\
\text { كريشن }\end{array}$ & $\begin{array}{l}\text { Plate } \\
\text { يليت }\end{array}$ \\
\hline $\begin{array}{l}\text { Coupon } \\
\text { كوين }\end{array}$ & $\begin{array}{l}\text { Break } \\
\text { بريك }\end{array}$ & $\begin{array}{l}\text { Order } \\
\text { آربر }\end{array}$ & $\begin{array}{l}\text { Train } \\
\text { ترين }\end{array}$ & مus & $\begin{array}{l}\text { Result } \\
\text { رزلت }\end{array}$ \\
\hline $\begin{array}{l}\text { Degree } \\
\text { بجرگي }\end{array}$ & $\begin{array}{l}\text { Report } \\
\text { ريورتت }\end{array}$ & $\begin{array}{l}\text { Library } \\
\text { لأببريري }\end{array}$ & $\begin{array}{l}\text { Teacher } \\
\text { تيججر }\end{array}$ & $\begin{array}{l}\text { Record } \\
\text { ركارب }\end{array}$ & $\begin{array}{l}\text { Blast } \\
\text { باست }\end{array}$ \\
\hline
\end{tabular}

Similarly the words like, Kitchen, Date, Car, Test, Time and Party are always used instead of their Sindhi equivalents owing to recurrent utilization in Sindhi print media. 
Intra-word mixing: The phenomenon of mixing codes in which speakers use the phrases and words in a conversation, and English with Sindhi are found to be mixed. The formation of numerous consistent terms in Sindhi language is a result of such type of mixing of internal words:

\begin{tabular}{|l|l|l|l|}
\hline Chaati race & Istari stand & Paan shop & Barqi fan \\
\hline
\end{tabular}

When adding these words by pluralizing some Sindhi words, especially the plural nouns in English, there is a tendency of mixing the code. Although this is a relatively a new practice, it is accepted by numerous speakers of Sindhi language:

\begin{tabular}{|l|l|l|l|}
\hline Masaalahas & Sufis & Minaars & Halwas \\
\hline
\end{tabular}

Intra-Substantial Mixing: Pakistani society adopts such type of mixing in words of English words in Sindhi sentences as a common practice. It is difficult for people to pronounce sentences that are composed of entire terms in Sindhi language. A few examples of such hybrid phenomenon have been given below:

- Asaankhay hopeful or positive response napayomilay.

$$
\text { (اسان كي هوي فل آريازيتوريسيانس نـ ييوملي) }
$$

"We are not receiving any hopeful and positive response".

- Tokhay promise karno pawando ta ton muhenji help kandein.

$$
\text { (توكي يرامز كرئويوندو تت تون منهنجي هيلٍ كندين) }
$$

"You will have to promise that you will help me".

- Asaankhay early morning hin program khay start karanghurjay.

$$
\text { (اسان كي ارلي مارننخ هن يروخرام كي استارت كرط گهرجي) }
$$

"We should start this programme early morning".

- Education ghat huwaan bawujood hoo witty aahay.

$$
\text { (ايجوكيثن گهت هئط باوجود هووِتي آهي) }
$$

"In spite of low education, he is a witty person".

Data analysis has shown that the terms are associated with the government and authorized organizations. They are substituted in Sindhi and utilized in English. English words related to government used in Sindhi print media:

\begin{tabular}{|l|l|l|l|l|}
\hline Judge & Chief Justice & Supreme court & High court & Assembly \\
\hline Senate & University & Search committee & Notification & Hand-out \\
\hline
\end{tabular}


Words of English language associated with courts being used in Sindhi print media as they are:

\begin{tabular}{|l|l|l|l|}
\hline Jail & Law and order & Supreme court & Magistrate \\
\hline $\begin{array}{l}\text { Jail } \\
\text { Superintendent }\end{array}$ & Barrack & Civil judge & $\begin{array}{l}\text { Anti-corruption } \\
\text { court }\end{array}$ \\
\hline
\end{tabular}

Terms utilized in English language related to Science and Technology:

\begin{tabular}{|l|l|l|}
\hline Rifle & Website & Revolver \\
\hline Email & Drone & Mobile phone \\
\hline Computer & Laptop & Internet \\
\hline
\end{tabular}

Words of English related to Armed forces utilized in Sindhi print media:

\begin{tabular}{|l|l|l|}
\hline Army chief & Police & Air force \\
\hline Rangers & Army & ISPR \\
\hline Navy & Coast guard & Missile \\
\hline
\end{tabular}

A number of other English words are widely utilized in Sindhi print media, such as the colours. They can be green, red and white. The names of items, like, pants and coats are examples.

English Words without substitute available in Sindhi language are used as they are. For example:

\begin{tabular}{|l|l|l|l|l|l|l|}
\hline $\begin{array}{l}\text { Polling } \\
\text { station }\end{array}$ & $\begin{array}{l}\text { Ballot } \\
\text { paper }\end{array}$ & Megawatt & $\begin{array}{l}\text { Returning } \\
\text { officer }\end{array}$ & $\begin{array}{l}\text { Load } \\
\text { shedding }\end{array}$ & $\begin{array}{l}\text { Presiding } \\
\text { officer }\end{array}$ & $\begin{array}{l}\text { Mobile } \\
\text { market }\end{array}$ \\
\hline
\end{tabular}

The study also showed that some words have alternatives, but the results proved to be part of Sindhi language, such as: hospital, intensive care unit, doctor, etc.

\section{FINDINGS AND DISCUSSION}

Research on the collected data have shown that the borrowing and mixing of codes, along with code conversion is important component in Sindhi print media along with Sindhi news channels in Pakistan.

It has been detected that the coding is practiced mainly at the word level in the Sindhi print media and occasionally at the phrase level. It is worth noting that it is usually a code noun. Most advances in science and technology have come from the West; therefore, most 
terms are in English. Pakistan's formal language is considered to be English and it is being utilized in majority of significant organizations. It is the language of courts, administration, armed forces, employment, innovation and the science. This has become an important aspect of Pakistani society, and even in national events to practice English. The phenomenon to mix the code and loanwords is easy to be found and understood. There are many reasons that why the Sindhi language is worth coding, changes the code, and borrows. First of all, the language of instruction in all educational institutions in Pakistan is English. The books provided by the Ministry of Education in most public schools are in English. Most books are written in English by the composers.

English is then adopted by the alternates as second language (L2). For communication in Sindhi, English is used as a feature of their Sindhi learning basis. Insufficient vocabulary is another major reason for code-mixing and loanwords in Sindhi print media. Phrases and words of English language are sometimes used by people when they communicate in Sindhi as they cannot think of a suitable term in Sindhi that could match the words in English. This is connected to prompt the credit because it mainly occurs when we use English vocabulary quickly instead to look for the exact word in Sindhi.

Another cause to use English in Sindhi newspapers is for the business resolutions; interviewees said that the proficient utilization of English in news items assists them in convincing customers and consumers because the utilization of English terminology has an upright influence on the way in various merchandises that are displayed. An additional motive is that why the Pakistanis use English in order to prove their status; according to a psycho-social survey conducted on the editors and reporters in using observation techniques, it was found that the psycho-social reasons were also there for including English words in Sindhi newspapers and the second thing found was related to code-mixing and loan words in English. The exact meaning uttered by judges, prime minister, the opposition leaders, actors, artists, politicians and other individuals is to be conveyed to the people. Doing this, the socio-linguistic status of the reporters and editors is proved. For them, the proficiency in English is a testament to their high education and economic status. Surprisingly, the opposite sex is another reason as the data analysis reveals an interesting motive for young people that work in Sindhi print media. 
Pakistani reporters that are working with the organizations of Sindh print media; often use English in their discussions to attract the attention and surprises of the opposite sex in the same organizations or the teenagers mix the code while they are enrolled in colleges and universities. Readers of the Sindhi newspapers believe that English code-mixing and loan words in the tabloids strengthen their language reinforce their skills, identity and image. Sometimes, in Sindhi media organizations, when the editors or the news editors have to use harsh and mean words on the errors of some junior staff, they said they could be found using English words as the metaphors on grounds that use the correct expressions in Sindhi. It can lead to terrible situations. The same thing at times is applied on the filing of certain news items for the Sindhi newspapers. The reporters use the same harsh words that are uttered by judges in English in the court during the hearing procedures. In addition to it, when the sensitive topics such as love, sex, and some physical infections become part and parcel of the news items, the reporters also use English because the same Sindhi terms may sound strange or misrepresent the true sense. Sometimes, the government ministers and opposition leaders tick off their political rivals in English on the Assembly floor in order to keep up the complexity. The reporters file the news by using the same English words in order to convey the true sense to the readers.

\section{CONCLUSION}

It is concluded that the reporters and editors often file the news items in Sindhi print media that incorporate English terms instead of the Sindhi equivalents as easily available. It is done to convey the exact meaning of certain English words to their readers. Mixing English codes with the Sindhi language newspapers is aimed to get across their messages to the readers accurately. Most importantly, the Sindhi newspapers' readers are unwilling to find the corresponding Sindhi terminologies that are explicitly under 'utilitarian' methodology. In addition, some English words that are used in the Sindhi print media have no analogous Sindhi words; while the available terms are in the vocabulary of passive users in a completely unknown form. Therefore, the reporters use English words to serve their communication purposes. 


\section{REFERENCES}

Amuda, A. (1989). Attitudes to code-switching: the case of Yoruba and English. Odu, New Series, 35.

Anzaro, I. F. (2018). An Analysis of Code-Switching in the Novel Critical Eleven by Ika Natassa (Doctoral dissertation, IAIN Ponorogo).

Ayeomoni, M. O. (2006). Code-switching and code-mixing: Style of language use in childhood in Yoruba speech community. Nordic Journal of African Studies, 15(1).

Bokamba, E. G. (1989). Are there syntactic constraints on code mixing? World Englishes, 8(3), 277-292.

Coulmas, F. (2005). Sociolinguistics: the study of speakers' choices. Cambridge: Cambridge University Press. Gal, S. (1988).

Crystal, D. (1987). Towards a 'bucket' theory of language disability: Taking account of interaction between linguistic levels. Clinical Linguistics \& Phonetics, 1(1), 7-22.

Ho, J. W. Y. (2008). Code choice in Hong Kong: From bilingualism to trilingualism. Australian Review of Applied Linguistics, 31(2), 18-1.

Hudson, R. A. (1996). Sociolinguistics. Cambridge University Press.

Kachru, B B. (1986). The alchemy of English: The spread, functions, and models of non-native Englishes. Uraba and Chicago Illionis: University of Illionis Press.

Kachru, B., (1983). The Indianization of English: The English Language in India. India: Oxford University Press.

Liu, P. (2006). Code-switching and Code-mixing (seminar paper). Germany: GRIN. Retrieved January 15, 2012, from http://www.grin.com/en /ebook/92496/code-switching-and-code-mixing\#inside

Martin, E. (1998). The use of English in written French advertising: A study of code-switching, code-mixing, and borrowing in a commercial context.

Mugheri, N. A., \& Lohar, S. A. (2018). Code-Mixing of English in the Sindhi Newspaper Daily Kawish, A Case Study. Language in India, 18(4).

Obserstein, K.L. (1996). Defining children's literature and childhood. In P.Hunt (Ed.) (1996). International companion: Encyclopedia of children's literature (pp.17-20). London: Roultedge.

Pfaff, C W. (1979). Constraints on language mixing: Intra-sentential codeswitching and borrowing in Spanish / English Language volume 55, (2), 291-318.

Poplack, S. (2001).Code-switching (linguistic). International encyclopedia of the social and behavioral sciences, 12, 2062-2065.

Rasul, S. (2009).Code-Mixing and Hybridization in Pakistan- Linguistic, SocioCultural and Attitudinal Perspectives.

Spolsky, B. (1998). Sociolinguistics (Vol. 1).Oxford university press.

Stockwell, P. (2002). Sociolinguistics: a resource book for students. London: Routledge.

The political economy of code choice. In M. Heller (Ed.) Code switching: Linguistic and anthropological perspectives (pp.247). The Hague: Mouton.

Wardhaugh, R. (1992). Introduction á sociolinguistic. Santiago de Compostela: Universidade. 